\title{
ДОСЛІДЖЕННЯ МОРФОЛОГІЧНОГО РІВНЯ ПОЕТИЧНОЇ МОВИ В АСПЕКТІ ЛІНГВОКРЕАЛОГІЇ: СУЧАСНИЙ СТАН І ПЕРСПЕКТИВИ
}

\author{
Скоробогатова О. О., Козлова А. Г.
}

\section{ВСТУП}

Сьогоднішня зацікавленість питаннями лінгвопоетики зумовлена особливостями поетичного пізнання світу й тими викликами, які ставить сучасність перед філологічною наукою. Суспільство потребує розуміння й послідовного вивчення мовного підгрунтя когнітивної картини світу, гуманітарна парадигма змінює вектор досліджень від ізоляціонізму до вивчення соціокультурних моделей світосприйняття, які формуються в мовленні, відбиваються в мові і водночас мають індивідуальне виявлення. Мовна діяльність все частіше стає об'єктом гуманітарних студій, іiі дослідження змінюють погляд на теоретичні

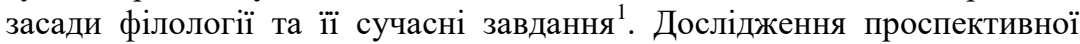
динаміки мови і мислення, посибілізм - вивчення можливого - як методологічний підхід у сфері гуманітарних досліджень передбачає, що мислення й мова містять власні набори можливостей (власну потенціальність), предмет і метод лінгвістичних розвідок взаємопов'язані та взаємообернені, креативна мовна діяльність може вивчатися не тільки історично (ретроспективно), але і проспективно.

Шляхи подолання кризи гуманітарних наук Михайло Епштейн убачає у зміні вектора діяльності: від накопичення знань до безпосередньої філологічної творчості. Учений закликає гуманітаріїв перейти від теоретичних узагальнень до практичної творчої діяльності, використання набутих теоретичних знань у напрямі гуманітарного винахідництва, наукової імагінації, мовних інновацій ${ }^{2}$. Гуманітарний складник надзвичайно важливий у таких актуальних сферах дослідницької діяльності, як створення штучного інтелекту, розширення світової інформаційної мережі, розроблення нових знакових систем. Розуміння цього надихає філологів на вивчення

${ }^{1}$ Просяник О. Фердинанд де Соссюр: деміфологізація концепції : монографія. Харків : Харківське історико-філологічне товариство, 2018. 276 с.

2 Эпштейн М. От знания - к творчеству. Как гуманитарные науки могут изменять мир. Москва ; Санкт-Петербург : Центр гуманитарных инициатив, 2016. $480 \mathrm{c}$. 
наявних і створення нових практик гуманітарного винахідництва, серед яких важливе місце посідає лінгвокреалогія.

Лінгвокреалогія як напрям філологічної діяльності $\epsilon$ творчою лабораторією, у якій досліджуються мовні й мовленнєві механізми колективного й індивідуального мислення, розвиток мовної картини світу, розробляються принципи й навіть конкретні механізми впливу лінгвістики на розвиток мови й когніції, на формування понять і уявлень, на розвиток креалогії й апперцепції.

Ідеї М. Епштейна корелюють з ідеєю продуктивної раціональності, яку сучасна епістемологія визначає як універсальну здатність розуму мислити послідовно і як здатність «породжувати нове знання в мінливих контекстах соціальної й пізнавальної практики» ${ }^{3}$ (тут і далі переклад російськомовних джерел українською мовою наш. - O. C., A. K.).

Історія цивілізації знає лінгвокреативний феномен, що існує в різних культурах і людських спільнотах. Це феномен поетичної творчості, який відповідає надвисоким вимогам лінгвокреалогії. Поезія як один зі способів пізнання світу пов'язана 3 історією людства, а філологія - 3 вивченням поезії, бо перші відомі філологічні дослідження орієнтовані саме на вивчення поетичних творів, давньогрецького, давньоіндійського, близькосхідного епосу.

XX століття в лінгвістиці пройшло під знаком підвищеного інтересу до поетичної мови. Ідею розуміння поезії як одного зі способів мислення висловив й обгрунтував Олександр Потебня. Його дослідження у сфері теоретичної поетики зумовили розвиток лінгвопоетики й лінгвостилістики у XX столітті. Систематично описаний, досить повно вивчений лексичний ярус поетичної мови, тоді як граматика, на жаль, довгий час залишалася на периферії філологічних пошуків. Причина цього криється, з одного боку, у певному автоматизмі використання морфологічних одиниць і правил, автоматизмі використання, розуміння та сприйняття граматики носієм мови, із другого - у меншій порівняно 3 лексикою варіативністю морфології поетичного тексту, іiі традиційній орієнтації на загальномовну граматичну норму.

\section{1. Поетична морфологія та морфологічна поетика як вектори дослідження морфологічного рівня поетичної мови й тексту}

Звернення лінгвістів до поетичної граматики традиційно пов'язують 3 ім'ям Романа Якобсона, роботи якого, присвячені граматиці поезії і поезії граматики, стали помітним явищем у світовому філологічному дискурсі. Сам Р. Якобсон посилається на ідеї Льва Щерби, якому

${ }^{3}$ Автономова Н. Открытая структура: Якобсон - Бахтин - Лотман - Гаспаров. Москва ; Санкт-Петербург : Центр гуманитарных инициатив, 2017. С. 9. 
належить пріоритет у використанні поняття «граматика поезії», що було прийняте фахівцями з деякою обережністю, бо свобода поетичної творчості, на думку багатьох, не поєднувалась із граматичними обмеженнями. Роман Якобсон послідовно деміфологізував питання граматичної, зокрема морфологічної, поетичної креаторики. Однак ані статті Л. Щерби, ані масштабні роботи Р. Якобсона, у яких підкреслюється роль граматичних значень в організації поетичного тексту, на загальну тенденцію ігнорувати рівень морфологічних одиниць або зменшувати їхню значущість у реалізації авторської концепції під час створення поетичних змістів принципово не вплинули, хоча сполучення «поезія граматики і граматика поезії» стало звичним для лінгвістичної спільноти, прикриваючи собою непропорційно малу кількість робіт у цій площині. Необхідно назвати імена Ірини Іонової, Якова Гіна, Людмили Зубової, Ірини Ковтунової, Леніни Черкасової, які вже в останні десятиліття XX сторіччя порушували загальну тенденцію, однак робіт у сфері поетичної морфології досі залишається непропорційно мало.

До початку XXI століття поетична граматика російської мови описується фрагментарно. У цей час «граматикалізація» поетичної мови (активне застосування поетами виразного та виражального потенціалу морфології й синтаксису) спричиняє збільшення праць на перетині граматики та поетики. Але якщо поетичний синтаксис вивчається досить системно, більшість спеціалістів у галузі лінгвопоетики звертаються до питань морфологічної виразності 3 погляду девіантності поетичних уживань, їх співвіднесення із загальномовною нормою. Такий підхід трапляється в дослідженнях Геннадія Зельдовича, Ольги Ремчукової, Наталії Фатєєвої, Михайла Епштейна. Найбільш значущі, на наш погляд, у цій царині монографії Людмили Зубової ${ }^{4}$. Дослідження регулярних способів поетичної актуалізації нормативних граматичних форм як самостійне завдання було вперше запропоноване лише наприкінці минулого століття. I воно досі залишається не вирішеним у повному обсязі.

Розглядаючи мовну діяльність у іiі поетичній функції, лінгвісти сформулювали тезу про поетичну мову як сферу максимальної реалізації можливостей мови національної, зокрема у сфері реалізації ії системного потенціалу. Водночас вивчення й опис структури граматичних категорій, загальномовних і власне поетичних функцій морфологічних форм i граматичних одиниць під кутом зору лінгвостилістики та лінгвопоетики представлено у спеціальних

4 Зубова Л. Современная русская поэзия в контексте истории языка. Москва : Новое литературное обозрение, 2000. 431 с. 
дослідженнях бідно. Зазвичай лінгвісти ідуть іншим шляхом, описують особливості ідіостилю того чи того автора як сукупність мовних одиниць різних рівнів, зокрема граматичного, що задіяні в будові творів, але морфології і в цьому разі не приділяють значної уваги.

У 70-80-ті роки минулого століття з'явились перші в царині поетичної граматики східнослов'янських мов монографічні роботи С. Срмоленко, I. Ковтунової, I. Іонової та низка дисертаційних досліджень, у яких розроблялися запропоновані цими вченими положення поетичної граматики. Значним кроком у зазначеному напрямі стали розвідки Я. Гіна, які, на жаль, дуже мало відомі навіть серед фахівців. Досліджень, у яких описані одиниці лексичного i фразеологічного рівнів із позицій лінгвопоетики й лінгвостилістики, як мінімум на порядок більше.

Морфологічна стилістика, що активно розвивалася в останній третині минулого століття, вивчає передусім експресивно виразний потенціал тих форм і категорій, граматичне значення яких у системі національної мови $є$ експресивно маркованим, слугує морфологічним підгрунтям формування експресивності, категорії оцінки або градуальності в тексті. У граматичних описах зазвичай дається коротка стилістична характеристика таких форм. Саме вони є об'єктом дослідження граматичної стилістики. Детально описані виразні можливості ступенів порівняння прикметників i прислівників, наказового й умовного способу дієслів. Окремі стилістичні характеристики одиниць морфологічного рівня розглядаються з огляду на механізми їхнього утворення, сфери використання та принципи відбору в наукових розвідках Т. Винокур і О. Ревзіної, значний крок у вивченні дієслівних категорій зроблено авторами «Поетичної граматики» і в роботах В. Бріцина.

Усе ще залишаються за межами системного опису й вивчення граматичні категорії й розряди слів з аналізом експресивно виразного й семантичного потенціалу форм, можливостей їхньої загальнопоетичної й індивідуально-авторської актуалізації та трансформації; немає послідовного граматичного опису віршового потенціалу морфологічних одиниць у парадигматиці та синтагматиці, а також вони недостатньо вивчені 3 погляду загальнопоетичного й індивідуального функціонування в поезії нового й новітнього часу. «Елементи морфологічної системи, значущі за своєю суттю в концептуалізації знань про дійсність» ${ }^{5}$, у структурі віршового тексту відіграють виразну

${ }^{5}$ Сопоставительная грамматика русского и украинского языков / Г. Басова и др. Киев : Наукова думка, 2003. С. 192. 
й образотворчу роль. Вивчення цієї ролі може проводитись у різних дослідницьких площинах.

Звісно ж, опис поетичного потенціалу граматичних категорій i форм, що заснований на аналізі загальномовних системних можливостей морфологічних одиниць, належить до сфери вивчення поетичної морфології. Як і звичайна граматика, поетична граматика покликана системно схарактеризувати граматичні одиниці, що представлені в мові (у нашому випадку - у мові поетичній): їхню семантику, прагматику, синтактику й епідигматику.

Застосування морфологічних одиниць та їхніх комбінацій не є хаотичним, воно вибудовується у складну багатовекторну систему. Одиниці функціюють нестандартно, підкорюючись не тільки граматичним, але й віршовим законам. Таке нестандартне функціювання, незважаючи на індивідуально-художні особливості текстів й ідіостилів, є предметом морфологічної поетики. Саме поетика дозволяє перейти від рівня опису граматичної семантики до аналізу поетичного змісту.

Виявлення кореляцій між граматичною формою і загальнопоетичним змістом є тим кроком, про необхідність якого писали ще О. Потебня й О. Веселовський. Можливість такого опису підтверджується численними прикладами аналізу конкретних віршів, що мають яскраве морфологічне оформлення, наприклад, зразками номінативного або інфінітивного письма, дослідженням образно-граматичного паралелізму тощо. Ці художні зразки морфолого-поетичного письма можна назвати класичними. Але навіть виявлення загальнопоетичних закономірностей морфологічної селекції досі перебуває у стадії поодиноких спроб. (До найбільш удалих із них ми можемо віднести дослідження О. Жолковського, результати яких представлені в роботі «Русская инфинитивная поэзия XVIII-XX веков : антология») ${ }^{6}$.

Розглянемо причини, у зв'язку 3 якими поетична морфологія і поетика морфологічних категорій і форм (морфологічна поетика) розроблені недостатньо. Перша й очевидна причина - максимальна стабільність морфології порівняно 3 іншими рівнями мови, певний автоматизм передавання морфологічної інформації. «Граматичне значення відображає диктат мовної системи», - стверджує Яків Гін ${ }^{7}$. Це найбільш чітке формулювання головної причини. «Вільна стихія» поезії в дослідницькому, а не лише в читацькому уявленні погано співвідноситься із граматичним диктатом. Л. Щерба, який уперше

${ }^{6}$ Русская инфинитивная поэзия XVIII-XX веков : антология / сост., вступ. ст. и примеч. А. Жолковского. Москва : Новое литературное обозрение, 2020. 560 с.

${ }^{7}$ Гин Я. Поэтика грамматического рода. Петрозаводск : КГПИ, 1992. С. 12. 
використав у філологічному дискурсі сполучення «граматика поезії», пише про те, що поєднання термінів «поезія» $\mathrm{i}$ «граматика» потребує мужності й дослідницької рішучості, бо правила граматики не створюються філологами, а виводяться на підставі вивчення мовного матеріалу. I хоча вираз «поезія граматики та граматика поезії» $з$ легкої руки Р. Якобсона міцно увійшов у філологічний обіг, граматика поезії, яка плідно вивчається на рівні синтаксису, у площині морфології досі або залишається граматикою відхилень, граматикою ненормативних авторських утворень, або розглядається фрагментарно. Сучасні дослідники визнають, що «можлива не тільки лексична, але й граматична творчість, хоча, як відомо, граматика - набагато більш стала й упорядкована частина мовної системи» $^{8}$, однак традиційно розглядають морфологічну творчість передусім у сфері порушення норми.

Ця позиція не враховує того факту, що рівень морфології, який $\epsilon$ найбільш сталим рівнем граматичної системи мови, має семантичну основу, використання потенціалу якої у віршовому просторі має свою специфіку. Крім того, форма морфологічних одиниць, яка змінюється в історичній перспективі дуже повільно і властива не окремим словам, а цілим морфологічним групам (розрядам), дозволяє поету перейти, згідно з Р. Якобсоном, $з$ «осі селекції на вісь комбінації», демонструючи динаміку й симетричність віршової організації, що притаманні поетичному тексту.

Друга причина відставання розвитку поетичної морфології від бурхливого руху інших лінгвопоетичних досліджень - нерівномірний опис одиниць морфологічного рівня поезії 3 позицій парадигматики й синтагматики. Парадигматика описана у граматичній стилістиці досить детально, тоді як особливості поетичної синтагматики морфологічних одиниць практично не вивчені. Можливо, це пов'язане 3 тим, що синтагматичний аспект аналізу віршової мови в аспекті поєднання морфологічних одиниць традиційно й успішно вивчається синтаксистами. Однак семантика і стилістика взаємодії граматичних одиниць - це не тільки семантика і стилістика синтаксичних конструкцій і послідовностей. Поняття віршового ряду, яке має в лінгвопоетиці широке тлумачення, і віршового тексту як єдності, яка потребує поряд 3 атомістичним холістичного вивчення, дозволяє говорити про співпозицію у віршовому ряді й поетичному тексті одиниць, що пов'язані синтаксичними відношеннями. Водночас питання смислового поєднання та взаємодії морфологічних опозитів і комплементарних форм у структурі віршових рядів різних типів та цілісного поетичного тексту досі в лінгвопоетиці не

8 Эпштейн М. Грамматическое творчество в речи и в языке: от аномалии к норме. Язык как медиатор между знанием и искусством : сборник докладов Международного научного семинара. Москва : Азбуковник, 2009. С. 31. 
розроблені. Винятком є деякі аспекти сучасних досліджень Людмили Зубової та Михайла Епштейна, які в низці випадків звертаються саме до цього аспекту поетичної творчості, розглядають граматичні зміщення й мікроаномалії, що трапляються в поетичних текстах, та досліджують вплив поетичної креалогії на розвиток сучасної російської мови.

Під час аналізу поетичного тексту виникає потреба в поєднанні синтагматичного й парадигматичного підходів, бо віршовий твір цілісний феномен, усі елементи якого взаємопов'язані, чим визначається необхідність інтегративного підходу до його вивчення. У поетичному тексті значущими є не тільки і не стільки окремі граматичні значення одиниць, а й сукупні значення, що виникають у результаті їхньої взаємодії. Ці сукупні значення виникають як у межах синтаксичних єдностей різного типу, так і за їхніми межами - на рівні фрагмента тексту, віршового ряду, строфи тощо, і тексту як єдності. До парадигматичного й синтагматичного параметрів взаємодії морфологічних одиниць додається параметр композиціональний, до синтагматичного й парадигматичного векторів опису поетичного тесту - вектор композиціональний.

Аналіз композиціональних відносин морфологічних одиниць у структурі поетичного тексту вбачається перспективним як з погляду виявлення потенціалу їх поєднань i комбінацій, так і 3 погляду опису й інтерпретації значної кількості поетичних творів, у яких морфологічні одиниці набувають експресивно виразної та виражальної функції й особливих поетичних змістів у протиставленні, сукупності, послідовності, лінійній і нелінійній. Виразний, змістовий і естетичний ефект у багатьох випадках визначається не мовною одиницею як такою, не iї адекватністю чи неадекватністю денотату та / або ліричній ситуації, відношенню до норми тощо, а фактом відбору, взаємодії одиниць, їхньою позицією одна до одної, особливостями домінування певних одиниць у структурі вірша й навіть фактом їхньої відсутності (наприклад, аналіз номінативних віршів Афанасія Фета Михайло Гаспаров виклав у статті, яку назвав «Фет безглагольный» ${ }^{9}$, підкресливши в назві не згущення субстантивних одиниць, а відсутність дієслів).

В основі багатьох композиціонально-синтагматичних i власне композиціональних відношень, що виникають у результаті актуалізації морфологічного потенціалу мовних одиниць у структурі поетичного тексту, лежать морфологічний відбір і співпозиція.

Украй важливим у вивченні поетичних одиниць усіх рівнів є поняття актуалізації. Воно введене в лінгвістичний обіг представниками Празького

${ }^{9}$ Гаспаров М. Фет безглагольный. Композиция пространства, чувства и слова. Избранные труды / М. Гаспаров. Москва, 1997. Т. II : О стихах. С. 21-32. URL: http://www.philology.ru/literature2/gasparov-97c.htm. 
лінгвістичного гуртка. Дослідники обстоювали тезу про те, що всі яруси та сторони системи мови, які автоматизовані в мові буденного спілкування, у поезії набувають самостійної значущості. Групування ж форм і засобів вираження (у нашому разі морфологічних форм і значень і способів їхньої актуалізації) спричиняється до їхньої актуалізації. Сучасні лінгвісти активно використовують це поняття. У ліричному творі, який має стислу форму, уміщуються багаторівневі накладання смислів, їхня апперцепція вимагає використання спеціальних прийомів.

Співпозиція грамем грунтується на відборі та близькій локалізації системно протиставлених морфологічних одиниць i їхніх поєднань, однорідних морфологічних одиниць та їхніх поєднань i на прийомі граматичної атракції. Між морфологічними одиницями у віршовому тексті виникають відношення однорідності, уподібнення, контрасту й додатковості. Ці значення формують граматичне тло, на якому відбувається розвиток поетичного сюжету, і самі стають елементами художньої динаміки, формують додаткові поетичні смисли. У структурі поетичного тексту відбувається реалізація естетичного і смислового потенціалу морфологічних категорій і форм.

Опис відношень між одиницями й тієї ролі, якої морфологічні співпозиції й послідовності набувають у поетичному функціонуванні, виходить за межі поетичної морфології та формує галузь, яку, на наш погляд, доцільно називати поетикою морфологічних категорій, або морфологічною поетикою. Проводячи дослідження в цьому напрямку, ми концентруємо основну увагу на художній реалізації внутрішнього потенціалу морфологічних категорій i форм, який притаманний їхній мовній природі. У цьому сенсі ми говоримо про поетику граматичних категорій і форм як про їхню «внутрішню форму», трактуючи термін не розширено, а буквально. Об'єктом вивчення є не тільки і не стільки стилістично марковані одиниці, скільки граматична структура всього тексту в єдності, семантичний складник граматичної будови поетичного тексту, що виявляється в результаті особливої впорядкованості та динамічної організації останнього й покликана до життя його когнітивноестетичною функцією.

\section{2. Основні принципи й вектори дослідження морфологічного рівня поетичної мови та поетичного тексту}

Нами сформульовано низку дослідницьких принципів-аксіом, які стали підгрунтям у вирішенні завдання створення систематичної поетичної морфології й морфологічної поетики української та російської мов. Їх можна використовувати й у вивченні поетичної морфології інших слов'янських мов. 
Перша аксіома - аксіома виразності. Ми припустили, що морфологічна форма i морфологічне значення (нормативне й ненормативне) у поетичному тексті можуть бути деяким чином актуалізовані або нейтралізовані. Одиниці всіх граматичних типів в умовах щільності віршового ряду є основою створення образності, формування ритму й поетичних смислів.

У деяких випадках відбувається поетична актуалізація граматичних форм і значень, яка створює ефект їхнього «згущення» й виділення, в інших - їх нейтралізація, яка створює ефект багатозначності й невизначеності поетичного тексту, що підвищує виразність i фасцинативність окремих морфологічних одиниць і тексту загалом. Розвиток тих чи тих поетико-граматичних тенденцій має історичний характер i зумовлений особливостями віршованого тексту різних періодів і жанрів, тематикою, проблематикою, традицією використання тропів і фігур та розвитком граматики відповідного періоду.

Наступна аксіома - аксіома експресивності порушення загальномовної морфологічної норми. Сутність цієї аксіоми полягає в тому, що будь-яке порушення норми (використання девіантних авторських одиниць i сполучень або нормативних форм у ненормативних значеннях чи в ненормативних умовах) у поетичному тексті підвищує експресивність цього тексту. Ця аксіома спирається на тезу Майкла Ріффатера, яка свідчить, що порушення передбачуваності сприйняття висловлювання підвищує його експресивність. Ми поділяємо думку про те, що норма в поетичному тексті відрізняється від загальномовної в бік варіантності та припустимості деяких порушень, але читацька апперцепція підсвідомо спирається на мовний досвід реципієнта тексту, тому мовна норма слугує тлом, на якому яскраво виділяються авторські новоутворення і граматичні відхилення.

Третя аксіома - парадигматичності. За нашими спостереженнями, у поетичному тексті актуалізуються мовні парадигматичні відношення не тільки на рівні лексики, що досить послідовно описано лексичною стилістикою поетичного тексту, але й на морфологічному рівні. У структурі вірша виділяються як бінарні, так i багаточленні морфологічні парадигматичні комплекси.

Четверта аксіома - аксіома цілісності (композиціональності). Ми вважаємо, що структура віршованого тексту, його онтологічні властивості (ритм, образність, дія закону єдності і щільності віршового ряду, динаміка форми) сприяють актуалізації та нейтралізації морфологічних форм і значень. Водночас актуалізація та нейтралізація визначені не тільки особливостями віршової або синтаксичної організації окремого речення, але й композицією, зв'язками на рівні цілого тексту. 
П'ята аксіома - аксіома переходу (трансферу) оказіонального у стале, а сталого - у загальнопоетичне (у деяких випадках у загальномовне). Ця теза стверджує, що оказіональні способи актуалізації чи нейтралізації форм i значень у разі повторного використання закріплюються в поетичному ідіостилі, що спричиняє формування поетичних закономірностей, рис поетичної мови певного періоду i, як наслідок, впливає на динаміку мови національної.

Шоста аксіома - аксіома інтенціональності - стверджує, що використання тих чи тих способів виділення й нейтралізації морфологічних значень і створення морфологічної основи поетичного наративу, ліричних і міфопоетичних мотивів, образів пов'язане в кожному конкретному випадку з певним поетичним авторським завданням.

Розв'язання поставленого завдання створення поетичної морфології як певного вектора розвитку лінгвопоетики ми розпочали 3 вивчення закономірностей поетичної актуалізації форм і значень іменника, прикметника, займенника, проводячи дослідження на матеріалі російської й української поезії нового й новітнього часу, іноді звертаючись до порівняльного аналізу та залучення віршового матеріалу інших слов'янських мов. Пізніше були розглянуті способи поетичної актуалізації службових частин мови й окремих форм дієслова.

Робота з віршовим матеріалом підтвердила аксіоматичні припущення. Нам удалося послідовно схарактеризувати способи поетичної актуалізації нормативних і ненормативних форм і значень категорій істоти / неістоти, роду, числа й відмінка іменників і прикметників, особових займенників, присвійних прикметників, субстантиватів як контамінованої форми імені і власних / загальних субстантивів.

Основним результатом стало виділення раніше не визначених загальнопоетичних способів актуалізації нормативних морфологічних форм і значень, серед яких головними є співпозиція (як результат поєднання у структурі віршового ряду форм і значень словоформ різних частин мови із загальним коренем або грамем, що належать до одного парадигмального ряду), селекція однорідних форм і значень, яка в максимальній реалізації спричиняє формування морфологічної домінанти тексту чи його фрагмента, i атракція (уподібнення морфологічних форм).

Ці способи були визначені як універсальні, що підтверджується матеріалом різних частин мови й різних слов'янських мов.

Що ми розуміємо під співпозицією? У повсякденному використанні наше граматичне мовне мислення вибіркове. Коли ми говоримо, наприклад, - Я отримав листа, або - Я отримав листи, значення однини чи множини іменника відображає кількісну реальність, тобто вказує, один чи кілька листів отримано. Категорія числа реалізована в 
одному зі своїх значень поряд з іншими граматичними значеннями словоформ. Коли М. Цвєтаєва пише: Так писем не ждут, Так ждут письма, числове значення виділене, створюється й передається додатковий поетичний зміст: лірична героїня чекає не будь-якого листа, а найважливішого, довгоочікуваного. (У поетичній строфі ця ідея розвивається й конкретизується, поєднуючись із темою щастя: <..> Внутри - словио. / И счастье. И это - всё). Такі співпозиції ми пов'язуємо 3 актуалізацією. Їхнє використання в поетичному тексті частотне. У тієї ж поетеси читаємо: <..> за тебя, который делом занят, / Не умереть хочу, а умирать. Завдяки співположенню інфінітивних форм дієслів доконаного i недоконаного виду створюється антитеза: протиставляються одноразовість і повторюваність процесу, що у віршовому контексті працює на формування ідеї безмежно сильного кохання, коли не просто не страшно померти за коханого, а навіть прийняти безмежну кількість мученицьких смертей. Співположення однокореневих дієслів, що формує парономазію, фіксуємо в Сергія Жадана: Якщио ти справді плануєш моє наступне життя, / я би радив тобі порадитися зі мною. Це сумно-іронічне звернення ліричного героя до ліричного адресата самого Всевишнього - утілює ідею про його прагнення якщо не бути хазяїном власної долі, то хоча б брати участь у іiі визначенні (нехай i в наступному житті). У віршованому рядку Ліни Костенко $A$ робота не жде. Ї̈ треба робить $<\ldots>$ співпозиція іменника зі спільнокореневим дієсловом актуалізує в ньому семантику дії.

3 поетичних структур, основою яких $\epsilon$ кореневий повтор у поєднанні із граматичною кореляцією, найбільш експресивні в українській та російськомовній поезії ті, що побудовані за сталими моделями. Сказки сказывать, горе горькое, мучиться мукой і подібні поєднання $є$ поетично продуктивними моделями, які здатні до контекстуальної трансформації. Натрапляємо в Лесі Українки на сnів заспівала, у П. Тичини - зелене зеленіє, вітра вітровіння, замулюється мулом, дзвінко дзвякали, у В. Свідзінського - невольники волі, у Миколи Зерова - n'є пиття, у Ліни Костенко - дзвонять дзвони, в Олександра Пушкіна - диво дивное, а в Йосипа Бродського - дивные дивы, у Юрія Левітанського - пустая пустыня та загадыввать загадки, в Анни Ахматової - послал посла, в Олександра Галича - горькая горесть и метет метель (кількість прикладів такого типу величезна).

Міжчастиномовна та внутрішньокатегоріальна співпозиція спільнокореневих слів виступає як загальнопоетичний прийом, що має прадавню міфопоетичну природу. Праці в галузі зіставної індоєвропейської лінгвістики і слов'янської лінгвопоетики свідчать про те, що такі комбінації дуже поширені. Вони мають велике когнітивне 
навантаження, бо відтворюють модель, у якій суб'єкт виконує типову, зразкову, притаманну дію або має типову властивість.

У разі посилення кореневого значення (позитивна модель) сполучення породжує додатковий смисл «природних», «типових» дій і властивостей. Співпозиції чудо чудное або співати nicнi в поезії нового та новітнього часу відтворюють додатковий поетичний зміст фольклорності, художньої традиційності, але, на відміну від моделей 3 постійним епітетом (добрий молодець або синє небо), традиційність не «розмиває» кореневе значення атрибута або предиката, а підкреслює його. Повтор кореня в цьому разі не є надлишковим, він виконує певну віршову смислову функцію.

Формульність або підкреслюється автором, водночас зазвичай відбувається актуалізація внутрішньої форми слова, як у попередніх прикладах, або знімається за допомогою переносу, парцеляції, дистантної локалізації спільнокореневих елементів, наприклад: Весёльмм треском / Трещит затопленная печь. (О. Пушкін). Співположення набувають нових можливостей як елементи складного віршового орнаменту, наприклад: Куди дзвонить? Там дзвонять тільки дзвони (Л. Костенко); Я начал, помню, жить / В ночь мутную, в пещерах Колизея. / И долго жил той жизнию, живой / Впервые <...> (В. Іванов). У віршованому тексті кореневий повтор є також основою повтору фонетичного, який поєднує алітерацію й асонанс, що іноді створює звукопис (треском трещит; дзвонять дзвони тощо).

Один із найбільш цікавих випадків співположення - багаточленне парадигмальне співположення, коли в одному віршовому просторі поєднуються не дві, а декілька морфологічних одиниць, що входять до граматичної парадигми. Порівняємо: Ворон к ворону летит, / Ворон ворону кричит (О. Пушкін), де зіставлені дві відмінкові грамеми, і Судьба, cудьбы, судьбе, судьбою, о судьбе (Б. Окуджава), де зіставлені п'ять відмінкових грамем, відтворена майже повна відмінкова парадигма слова. Найважливіший для російської мовної картини світу концепт «доля» («судьба») поет виділяє за допомогою прийому створення морфологічної парадигмальної повноти.

Експресивність і семантичну насиченість прийому парадигмального морфологічного представлення добре розуміють поети і філологи. Свої мемуари Юрій Шевельов назвав «Я - мене - мені <..> (i довкруги): Спогади». Сучасний поет Борис Херсонський створює цикл віршів під назвою «Личные местоимения», окремі вірші якого називаються «Я», «Ты», «Мы», «Вы», «Он», «Она», «Оно», «Они». Марина Цвєтаєва у значенні «завжди» використовує парадигму часу: Буду грешить, как грешу, как грешила, со страстью < ..> , а білоруський поет Володимир Короткевич пише про свою творчість: Быў. Ёсиь. Буду. 
Парадигма часу дієслова регулярно використовується для вираження повноти часу i вже стала традиційним поетичним прийомом, не втративши свого мовного сукупного значення: был, есть, будет, використані поруч, передають значення «завжди». Цей прийом і цей зміст знайдений поетами, а використовується всіма, сьогодні він функціює в різних сферах мовленнєвої діяльності: у рекламі, масмедіа, розмовному стилі мовлення.

Ще один спосіб актуалізації значень - селекція, або відбір. Він заснований на тому, що автор свідомо чи підсвідомо відбирає грамеми одного типу, завдяки чому створюється згущення цих грамем і формується морфологічна домінанта тексту чи його частини. Найвідоміший приклад граматичної домінанти - так зване називне письмо. Добре відомий вірш А. Фета Шепот, робкое дыханье. / Трели соловья. / Серебро и колыханье / Сонного ручья. У російській поезії регулярною є також інфінітивна домінанта: Февраль. Достать чернил и плакать! / Писать о феврале навзрыд <..> (Б. Пастернак). Інфінітивний відбір відрізняється від номінативного тим, що створює не суцільну, а дискретну віршову домінанту.

У деяких випадках формування морфологічної домінанти служить елементом мовної гри, за допомогою селекції створюються яскраві граматичні феномени, як, наприклад, вірш Олексія Апухтіна «Когда будете, дети, студентами <...>»:

Когда будете, дети, студентами,

Не ломайте голов над моментами,

Над Гамлетами, Лирами, Кентами,

Над царями и над президентами,

Над морями и над континентами,

Не якшайтеся там с оппонентами,

Поступайте хитро с конкурентами.

Очевидна домінанта орудного відмінка формує граматичне тло, яке допомагає визначити вірш як поетичну гру та надає йому жартівливого характеру. Крім того, згущення форм орудного відмінка в позиції рими перетворює вірш на монорим. Іван Чудасов висловлює думку, що повторюваність однієї рими символізує «одноманітність життєвих шляхів сучасного поетові покоління» ${ }^{10}$.

В інших випадках морфологічний відбір має імпліцитний підсвідомий характер і може виділятися лише на підставі ретельного морфологічного аналізу. Але і в такому разі граматичне тло, що утворюється, стає суттєвим елементом змісту вірша. Досить згадати,

10 Чудасов И. Монорим. Введенская сторона : журнал об искусстве для школьников, учителей и родителей. URL: https://art-storona.ru/monorim/. 
наприклад, вірш М. Лермонтова «Сосна» («На севере диком <..>»), блискучий аналіз якого, проведений Львом Щербою, став поштовхом до формування стійкого філологічного інтересу до граматики поезії у ХХ столітті.

\section{На севере диком стоит одиноко}

На голой вериине сосна.

И дремлет, качаясь, и снегом сыпучим

Одета, как ризой, она.

И снится ей всё, что в пустыне далекой,

В том крае, где солниа восход,

Одна и грустна, на утесе горючем

Прекрасная пальма растет.

Дослідник зауважує, що цей вірш - вільний переклад поезії Генріха Гейне, де образи сосни i пальми, що не можуть поєднатися, сприймаються як образи закоханих. Цей поетичний смисл формується завдяки тому, що сосна і пальма в німецькій мові протиставлені за родом. У вірші Михайла Лермонтова, на думку Л. Щерби, мотив розлуки закоханих зникає, тому що обидва іменники належать до жіночого граматичного роду. Учений стверджує, що основний мотив вірша М. Лермонтова - мотив самотності.

У результаті розгляду морфологічної структури цього вірша ми 3'ясували, що не тільки словоформа одна безпосередньо вказує на цей граматичний смисл, маркує його, але й загальне морфологічне числове тло всього вірша. У ньому всі словоформи 3 повною числовою парадигмою функціюють у формі однини. Саме сингулярна форма на підсвідомому рівні передає ідею самотності. В ідіостилі М. Лермонтова, крім цього вірша, $є$ ціла низка творів, що містять мотив самотності, який на морфологічному рівні вибудовується завдяки селекції форм однини. Поступово формується певна поетична традиція. У російській поезії XIX-XXI століть виникає поетична зв'язка: сингулярність (однина) - самотність. Було виділено більше 800 сингулярних віршованих текстів із наскрізною домінантою однини. За винятком кількох віршів (нами зафіксовано не більше 10), усі вони містять мотив самотності. У деяких випадках це екзистенційна самотність, в інших - творча, дружня, вимушена, пов'язана з від'їздом, засланням, або любовна, але граматична основа цих віршів однакова. Розглянуто низку поетичних смислів, що пов'язані із сингулярною домінантою й формуванням мотиву самотності, причому ми відзначаємо, що їх перелік може бути розширений i $є$ принципово відкритим. 
Дослідження поетичних мотивів, які мають стале граматичне вираження в мові, потребує продовження. Якщо відповідь на питання, що передає домінанта часу дієслова, досить прозора (хоча й тут іноді трапляються несподіванки), то вивчення того, що передає згущення субстантиватів чи онімів певного типу, грамем того чи того відмінка, актуалізація дієприкметників і дієприслівників потребує кропіткого аналізу. Причому результати цих спостережень можуть бути використані не лише у граматичних описах i аналізі поезій, але й у практичних посібниках зі стилістики, під час створення рекламних текстів, у масмедіа, для вивчення вербальних маніпулятивних практик. Граматичне тло фасцинативного тексту підсвідомо сприймається читачем і пов'язує смисл тексту з певним мотивом.

Зрозуміло, що в поетичних текстах, написаних різними мовами, випрацьовуються різні морфолого-поетичні зв'язки та різні закономірності створення домінант. Наприклад, згущення лексем середнього роду, що називають живих істот, у російському художньому дискурсі зазвичай має негативний характер або вказує на відстороненість від гендеру, в українському ж існує більша група іменників середнього роду, що називають недорослих людей і тварин, у разі згущення яких текст чи його фрагмент зазвичай забарвлюється позитивно.

Актуалізація одиниць морфологічного рівня відбувається також за допомогою атракції.

Поняття атракції використовує Федір Буслаєв, в активну філологічну практику його ввів Олександр Потебня. Учений, досліджуючи «атракцію форми», відзначає, що давність й активність зворотів із морфологічною атракцією дуже висока. Приклади синтаксичної атракції, не використовуючи терміна, наводить Юрій Шевельов. Розглядаючи твір, написаний називним віршем, учений зауважує, що речення, які в інших контекстах розглядалися б як неповні, в оточенні односкладних називних речень ототожнюються 3 ними. Науковець підкреслює, що в такому разі головною стає функція, помножена на вплив контексту ${ }^{11}$.

У поетичному мовленні й у деяких дискурсах, що характеризуються підвищеною експресивністю, атракція форм активно використовується як засіб версифікації й мовної гри: и на мускулы-деревья / nадает ментол мороза (Д. Арбеніна). Замість сполучення мускуль деревьев поет використовує субстантивний біном мускуль-деревья.

11 Шевельов Ю. До питання про генезу й природу називних речень. Харків : Харківське історико-філологічне товариство, 2012. С. 53. 
Морфологічна атракція досить поширена в російській і українській поезії, але регулярними стають різні зразки форм, що уподібнюються.

$\mathrm{y}$ російському поетичному дискурсі найтиповішим прикладом граматичної атракції $\epsilon$ надлишкове використання прийменника у сполученнях іменника з узгодженим прикметником, дієприкметником або займенником-прикметником: как $\boldsymbol{y}$ моря $\boldsymbol{y}$ Каспийского <... , по старой по дороге по Калужской (М. Цвєтаєва). Таке використання може ускладнюватися надлишковим повтором прикметника при однорідних членах речення, використанням співвідносних префіксів, включенням у віршову єдність сталих виразів із прийменником, наприклад: На всякий случай на пожарный / я в Шереметьево приду (В. Доліна).

В українській поезії поряд із цією сталою моделлю, наприклад, Біжиш через всю Україну до самих до гір Kарпат <..> (Б. Херсонський), активно використовується атракція кличних форм: від відомого прикладу в Павла Тичини $O$ панно Інно, панно Інно, де морфологічна атракція поєднується 3 паронімічною, до поетичного звернення Івана Драча до Володимира Калашника Семеновичу мій Калашнику, мій Володимире, мій брате <..>, де ряд кличних форм створює поетичний ланцюжок, приковує до себе увагу читача.

Поширені приклади використання атракції як прийому мовної гри: старший ключ в шкатулке лаковой / ноч кривой а реч прямой <..> (Б. Кенжеєв). Ненормативне узгодження актуалізує значення чоловічого роду морфологічних оказіоналізмів ноч та реч, що підкреслюється порушенням правопису. В авангардній поезії прийом набуває складних форм, виступає римою-індикатором у текстах, що позбавлені традиційного членування й пишуться «у рядок», іноді поєднуються 3 паронімічною й фоносемантичною атракцією, наприклад: Поздравляю героев с венцом и делу концом (Д. Биков). У деяких випадках атракція організовує значні фрагменти тексту й навіть цілі тексти. Число одиниць різного рівня, які піддаються уподібненню в експресивних дискурсах, постійно зростає. Це одна із причин того, що вивчення граматичної атракції $є$ актуальним.

Виділені способи актуалізації можуть поєднуватись, створювати примхливий малюнок вірша, як, наприклад, у поезії Зої Езрохі «Поэт! Не бойся тавтологий $<\ldots>>$ », домінантою якої слугують атрибутивносубстантивні співпозиції масляное масло, светлый свет, солнечное солнце, лунная луна; дом домамен, дождь дождлив, зверь зверин, ум умен, дело дельно, страшен страх, жизнь жива, смерть смертельна.

У першій частині вірша натрапляємо на поєднання таких способів актуалізації граматичних форм, як селекція моделі та співпозиція спільнокореневих іменника i повного прикметника у функції 
означення, а у другій домінантною стає співпозиція іменника і короткої форми прикметника, що виконує функцію присудка, тобто одна граматична модель породжує іншу:

Поэт! Не бойся тавтологий,

Окольных троп не проторяй.

Пусть негодует критик строгий,

Ть удивленно повторяй:

«Какое масляное масло!

Какой на свете светлый свет!»-

И ты поймешь, как много смысла

Там, где его, казалось, нет.

Пусть химик видит фтор и стронщий,

Тебе же-истина видна:

Какое солнечное солнце!

Какая лунная луна!

Среди полян, машин и башен

Броди восторженно один

И бормочи: «Как дом домашен!

Как дождь дождлив! Как зверь зверин!

Как ум умен, как дело дельно,

Как страшен страх, как тьма темна!

Как жизнь жива! Как смерть смертельна!

Как юность юная юна!

Тут бачимо й нормативні прикметникові форми, і нетипові (дом домашен, зверь зверин), які сформовані завдяки атракції з нормативними. Завершує поезію поєднання обох моделей. В останньому рядку використані іменник, повна й коротка форми прикметника: юность юная юна. Поетична мовна гра формується на підгрунті морфологічного потенціалу мовних одиниць. Авторка поєднує типові прийоми актуалізації, завдяки чому створюється ефект «надлишковості», що підкреслює загальну думку поетеси про повноту життя, іiі заклик до митців описувати цю повноту.

Створення систематичної поетичної граматики, що співвіднесена із загальною граматикою російської, української, а також інших слов'янських мов, $є$ найближчою перспективою розвитку поетичної морфології.

Дослідження морфології поетичного тексту може відбуватися й у зворотному напрямі - від поетики тексту до виявлення граматичної основи 
того чи того поетичного змісту, який у ньому виявляється. Морфологічні характеристики віршового тексту здатні формувати його художню структуру, часто пов'язані з розвитком сюжету й побудовою композиції. Граматична парадигма, морфологічні співположення й морфологічний ритм в українській і російській поетичній мові нового й новітнього часу виступають як складники композиційно-сюжетної динаміки.

Виділення й дослідження поетико-морфологічних мотивів, морфологічних домінант різних типів, граматичної основи окремих лінгвокультурних типажів, бінарних опозицій, універсальних знакових комплексів різних типів, тобто розвиток лінгвістики у просторі морфологічної поетики, значущі не тільки для розуміння особливостей поетичного світосприйняття, але й для лінгвокреаторики загалом, бо закономірності, що виявляються, спостерігаються і в інших типах фасцинативних текстів: релігійних, рекламних, політичних. Крім того, динаміка розвитку поетичної мови впливає на розвиток мови літературної, й активні практики експресивного смислоутворення пов'язані 3 когнітивною поетикою, поетичною креаторикою й теорією сприйняття.

\section{ВИСНОВКИ}

У дослідженні розглянуті причини зацікавлення сучасних лінгвістів питаннями морфології поетичної мови. Зміна вектора лінгвопоетичних студій у бік морфологічного аналізу поетичного тексту пов'язана із граматикалізацією сучасних фасцинативних дискурсів: поетичного, медійного, політичного, різних типів інтернет-спілкування; а також зацікавленістю суспільства в розвитку лінгвокреативних практик. 3'ясовані причини недостатнього розвитку в минулому дослідження морфологічного рівня поетичної мови, серед яких імпліцитність наявної в тексті морфологічної інформації й автоматизм іiі сприйняття, як наслідок, - недостатність у носіїв мови граматичної рефлексії; непослідовність холістичного інтегративного підходу до аналізу віршової мови. Виокремлені напрями дослідження: поетична морфологія як встановлення креативного потенціалу системи мовних одиниць і категорій і морфологічна поетика як вивчення можливостей одиниць морфологічного рівня в передачі тих чи тих поетичних смислів. Сформульовані принципи-аксіоми, що становлять підгрунтя сучасних поетико-морфологічних студій: аксіома виразності; аксіома експресивності порушення загальномовної морфологічної норми; аксіома парадигматичності; аксіома цілісності, або композиціональності; аксіома трансферу.

Описані основні способи актуалізації морфологічних значень у структурі східнослов'янських поетичних текстів: співпозиція протилежних або комплементарних граматичних одиниць; селекція, 
наслідком якої буває згущення в тексті одиниць одного типу й формування морфологічної домінанти тексту або його фрагмента; атракція (уподібнення) одиниць у структурі тексту.

Перспективу розвитку цього напряму лінгвопоетики вбачаємо в застосуванні теоретичних положень поетичної морфології й морфологічної поетики для аналізу інших текстів фасцинативного типу; можливість застосування досліджених прийомів актуалізації й нейтралізації мовних значень у практиці сучасної лінгвокреалогії; зіставлення виразного й виражального креативного потенціалу різних мов і виокремлення мовно-поетичних універсалій.

\section{АНОТАЦІЯ}

У праці розглянуті причини зацікавлення сучасних лінгвістів питаннями морфології поетичної мови: граматикалізація фасцинативних дискурсів, розвиток інтернет-спілкування, оновлення лінгвокреативних практик. Серед причин недостатнього розвитку поетичної морфології у XX столітті названі автоматизм сприйняття морфологічної семантики, недостатність граматичної рефлексії, непослідовність холістичного підходу до аналізу віршованої мови. Охарактеризовані основні напрями дослідження: поетична морфологія й морфологічна поетика. Сформульовані аксіоми, що становлять підгрунтя сучасних лінгвокреативних студій. Описані основні способи актуалізації морфологічних форм і значень: співпозиція, селекція, атракція. Перспектива розвитку вивчення поетичної морфології й морфологічної поетики вбачається в застосуванні прийомів лінгвопоетичного аналізу до вивчення фасцинативних текстів інших типів, зіставлення виразного й виражального креативного потенціалу різних мов і виокремлення мовно-поетичних універсалій.

\section{ЛІТЕРАТУРА}

1. Автономова Н. Открытая структура: Якобсон - Бахтин Лотман - Гаспаров. Москва ; Санкт-Петербург : Центр гуманитарных инициатив, 2017. 509 с.

2. Гаспаров М. Фет безглагольный. Композиция пространства, чувства и слова. Избранные труды / М. Гаспаров. Москва, 1997. Т. II : O стихах. С. 21-32. URL: http://www.philology.ru/literature2/ gasparov-97c.htm.

3. Гин Я. Поэтика грамматического рода. Петрозаводск : КГПИ, 1992. $162 \mathrm{c}$.

4. Глебкин В. Смена парадигм в лингвистической семантике: от изоляционизма к социокультурным моделям. Москва ; Санкт-Петербург : Центр гуманитарных инициатив, 2014. 368 с. 
5. Зубова Л. Современная русская поэзия в контексте истории языка. Москва : Новое литературное обозрение, 2000. 431 с.

6. Просяник О. Фердинанд де Соссюр: деміфологізація концепції : монографія. Харків : Харківське історико-філологічне товариство, 2018. $276 \mathrm{c}$.

7. Русская инфинитивная поэзия XVIII-XX веков : антология / сост., вступ. ст. и примеч. А. Жолковского. Москва : Новое литературное обозрение, 2020.560 с.

8. Самсоненко Н. Морфологічна домінанта поетичного тексту (на матеріалі російськомовної поезії XIX-XX століть) : автореф. дис. ... канд. філол. наук. Харків, 2018. 20 с.

9. Сопоставительная грамматика русского и украинского языков / Г. Басова и др. Киев : Наукова думка, 2003. 534 с.

10. Чудасов И. Монорим. Введенская сторона: журнал об искусстве для школьников, учителей и родителей. URL: https://art-storona.ru/monorim/ (дата звернення: 29.11.2020).

11. Шевельов Ю. До питання про генезу й природу називних речень. Харків : Харківське історико-філологічне товариство, 2012. 135 с.

12. Щерба Л. Избранные работы по русскому языку. Москва : Учпедизд., 1957. 188 с.

13. Эпштейн М. Грамматическое творчество в речи и в языке: от аномалии к норме. Язык как медиатор между знанием и искусством : сборник докладов Международного научного семинара. Москва : Азбуковник, 2009. С. 31-38.

14. Эпштейн М. От знания - к творчеству. Как гуманитарные науки могут изменять мир. Москва ; Санкт-Петербург : Центр гуманитарных инициатив, 2016. 480 с.

\section{Information about the authors:} Skorobohatova O. O.,

Doctor of Philology, Associate Professor, Professor at the Department of Foreign Literature and Slavic Languages H. S. Skovoroda Kharkiv National Pedagogical University 29, Alchevskyh str., Kharkiv, 61002, Ukraine

Kozlova A. H., Candidate of Philological Sciences, Associate Professor at the Department of Foreign Literature and Slavic Languages H. S. Skovoroda Kharkiv National Pedagogical University 29, Alchevskyh str., Kharkiv, 61002, Ukraine 